\title{
A Water Radiolysis Code for the Irradiation Loop System*
}

\author{
Satoshi HANAWA ${ }^{* *}$, Tomonori SATOH ${ }^{* * *}$, Yuichiro MORI ${ }^{* *}$, \\ Jin OOGIYANAGI ${ }^{* *}$, Yoshiyuki KAJI ${ }^{* * *}$ and Shunsuke UCHIDA ${ }^{* * *}$ \\ ${ }^{*}$ Nuclear Safety Research Center, Japan Atomic Energy Agency, \\ ***Nuclear Science and Energy Directorate, Japan Atomic Energy Agency, \\ 2-4 Shirakata Shirane, Tokai-mura, Naka-gun, Ibaraki-ken, 319-1195 Japan \\ E-mail: hanawa.satoshi@jaea.go.jp
}

\begin{abstract}
In order to evaluate the water chemistry in the irradiation field during IASCC irradiation test, a water radiolysis code for the irradiation loop system was developed. In the water radiolysis code, a multiple node model was introduced since the irradiation loop system has a wide rage temperature distribution as well as dose distribution. To investigate applicability of the developed water radiolysis code, water chemistry at the water sampling point of the irradiation loop system was measured and compared with analytical results under several water chemistry conditions. Further, water chemistry distribution in the in-pile region as well as in the out-pile region was calculated by the developed water radiolysis code.
\end{abstract}

Key words: Water Radiolysis Code, IASCC, Water Chemistry, Irradiation Research, JMTR

\section{Introduction}

Irradiation assisted stress corrosion cracking (IASCC) is recognized as an important degradation issue of the core-internal material for aged Boiling Water Reactors (BWRs). Therefore, the irradiation loop system has been developed and installed in the Japan Materials Testing Reactor (JMTR) to perform the IASCC irradiation test. In the IASCC irradiation test, water chemistry at the irradiation field is one of the most important key parameters because it affects initiation and propagation of cracks. It is, hence, important to know the water chemistry conditions which simulate BWR's beforehand in view point of advanced irradiation test. On the other hand, it is well known that the measurement of the water chemistry at the irradiation field is quite difficult. Therefore the water radiolysis code for irradiation loop system was developed based on the WRAC code ${ }^{(1)}$. In the water radiolysis code, direct generation of radiolytic species due to radiation energy deposition in the water, secondary generation and disappearance are introduced. Typicality of the water radiolysis analysis on the irradiation loop system is treatment of wide range temperature distribution, i.e. R.T. to about $561 \mathrm{~K}$. To treat such a wide range temperature distribution, multiple nodes model is introduced in this code.

In order to confirm the applicability of the developed water radiolysis code, water chemistry in the irradiation loop was calculated. Further, experiments to measure the water chemistry of irradiation loop system were performed. Obtained experimental data were compared with the calculated result. This paper describes the modeling of the water radiolysis code for irradiation loop system and the applicability of the developed water radiolysis code. 


\section{Overview of the irradiation loop system}

A schematic diagram of the irradiation loop system is shown in Fig.1. The irradiation loop system consists of the water control unit (WCU) and capsules. Major specifications of the WCU are described in Table 1. The WCU supplies high temperature and high pressure water in order to simulate BWR's condition. In the water conditioning tank, $\mathrm{O}_{2}$ concentration and $\mathrm{H}_{2}$ concentration are controlled by bubbling of mixed gas of oxygen-helium, hydrogen-helium or pure helium. Two of the three main pumps usually operate to prevent loss of flow from the safety point of view. To reduce fluctuation of flow rate, the main pump of three plungers is employed and a surge tank of forty litters is installed at outlet of the main pumps. At the downstream of the regenerative heat exchanger, feeding water line is divided into five paths to the capsules. Headers and coolers of the high capacity are employed to maintain the temperature of feeding water because $100 \%$ of flow rate should be cooled for purification and then heated again for temperature control of specimens. Instrumentation for on-line monitoring is provided and batch sampling can also be done for water chemistry analysis. In the water chemistry measurement, $\mathrm{O}_{2}$ concentration, $\mathrm{H}_{2}$ concentration and conductivity are measured by on-line monitoring whereas $\mathrm{H}_{2} \mathrm{O}_{2}$ and impurities are measured by batch sampling. In the irradiation loop

Table 1 Major specifications of the WCU.

\begin{tabular}{c|l}
\hline Capacity & $\begin{array}{l}5 \text { capsules } \\
\text { Temperature 593K (Max.) } \\
\text { Pressure 10MPa (Max.) } \\
\text { Flow Rate } 0.2 \mathrm{~m}^{3} / \mathrm{h} / \text { capsule }\end{array}$ \\
\hline $\begin{array}{l}\text { Temp. of specimens } \\
\begin{array}{l}\text { Conductivity } \\
\text { Impurities }\end{array}\end{array}$ & $\begin{array}{l}<61 \mathrm{~K}_{-26 \mathrm{~K}}^{+14 \mathrm{~K}} \text { for all specimens } \\
\mathrm{SO}_{4}{ }^{2-}<5 \mathrm{ppm} \\
\mathrm{Fe}, \mathrm{Cr}<10 \mathrm{ppb} \\
\text { controllable between } 10-200 \mathrm{ppb} \\
\text { controllable below } 1 \mathrm{ppm}\end{array}$ \\
$\begin{array}{l}\text { Dissolved Oxygen } \\
\text { Dissolved Hydrogen }\end{array}$ & \multicolumn{2}{l}{}
\end{tabular}

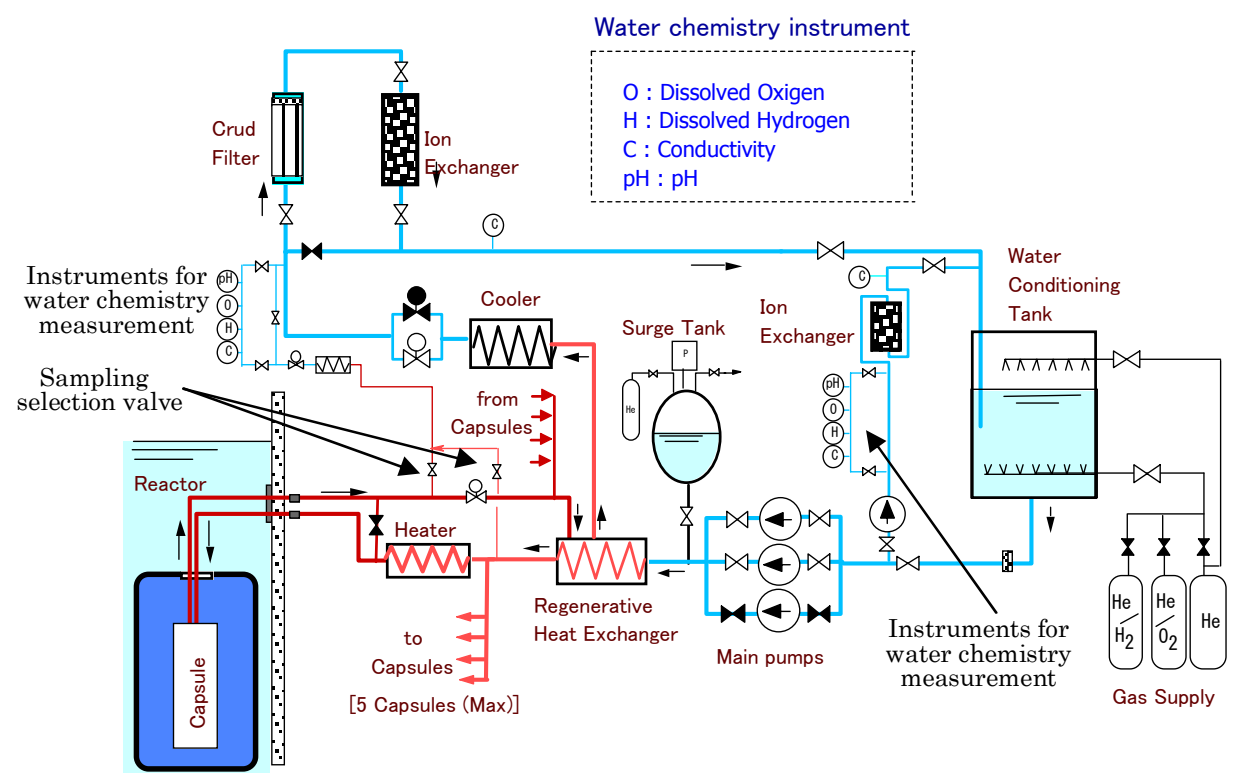

Fig. 1 A schematic diagram of the irradiation loop system. 
system, water chemistry at the outlet of the water conditioning tank, inlet as well as outlet of in-pile region can be measured.

Schematically drawn cross section of a capsule ${ }^{(2),(3)}$ is shown in Fig.2. A capsule contains several types of irradiation specimens such as compact tension (CT) specimens, uniaxial constant load (UCL) specimens and so on. Temperature of test specimens is controlled by the saturation temperature of feeding water. By controlling the water pressure, temperature of all specimens in a capsule is controlled within the range from $535 \mathrm{~K}$ to $575 \mathrm{~K}$ during irradiation experiments.

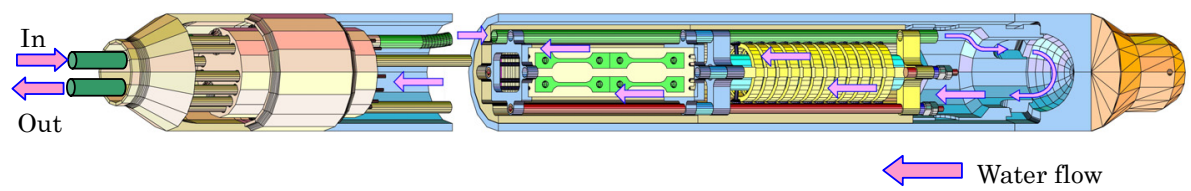

Fig. 2 A schematic diagram of a capsule.

\section{Development of Water Radiolysis Code}

In order to evaluate the water chemistry in the irradiation loop system, the water radiolysis code (WRAC-JM) was developed based on the WRAC code ${ }^{(1)}$. In the WRAC-JM code, direct generation of radiolytic species due to radiation energy deposition in the water, secondary generation and disappearance caused by their interaction, interaction with surfaces are introduced. Further, a multiple node model has been introduced since the irradiation loop system has a wide rage temperature distribution as well as the dose distribution. The basic equations are shown in Eq.(1),

$$
\begin{aligned}
\frac{\partial C_{i}^{k}}{\partial t}=g_{i}^{\gamma} Q^{g k} & +g_{i}^{n} Q^{n k}+\sum k_{m n}^{i} C_{m}^{k} C_{n}^{k}-C_{i}^{k} \sum k_{i s} C_{s}^{k} \\
& +\sum k_{m n}^{w i} C_{m}^{k} C_{n}^{k}-C_{i}^{k} \sum k_{i s}^{w k} C_{s}^{k}+C_{i}^{k-1} \frac{G_{i n}^{k}}{V^{k}}-C_{i}^{k} \frac{G_{o u t}^{k}}{V^{k}}
\end{aligned}
$$

where $C_{i}$ :concentration (mol/l), $g$ :G-value $(1 / 100 \mathrm{MeV}), \gamma: \gamma$ ray, n:neutron, $Q$ : absorption dose rate $(\mathrm{Gy} / \mathrm{s}), \quad V$ :volume $\left(\mathrm{m}^{3}\right), \quad k$ :reaction rate constant $(1 / \mathrm{mol} / \mathrm{s}), k^{w}$ :reaction rate constant with surface $(1 / \mathrm{mol} / \mathrm{s}), G_{\text {in }}$ and $G_{\text {out }}$ : flow velocity at inlet and outlet of the node, respectively. The first and second terms of right side are direct generation of radiolytic species by $\gamma$ ray and neutron. In this code, eight kinds of radiolysis products; $\mathrm{e}^{-}, \mathrm{H}, \mathrm{H}^{+}, \mathrm{OH}$, $\mathrm{OH}^{-}, \mathrm{H}_{2}, \mathrm{H}_{2} \mathrm{O}_{2}, \mathrm{HO}_{2}$ are considered. G-values ${ }^{(4)}$ of radiolytic species at $558 \mathrm{~K}$ employed in this study are shown in Table 2 . The third and forth terms are secondary generation and disappearance by their interaction. The fifth and sixth terms are generation and disappearance with surface. The seventh and eighth terms are connection with adjacent nodes. Schematic diagram of node connection is shown in Fig.3. As shown in this figure, initial condition of the adjacent node is given by following simple formula;

$$
C_{i}^{j, \text { in }}=C_{i}^{j-1, \text { out }}
$$

where $C_{i}^{j, \text { in }}:$ initial concentration at node $\mathrm{j}(\mathrm{mol} / \mathrm{l}), C_{i}^{j-1, \text { out }}$ : output concentration at node $\mathrm{j}-1$ $(\mathrm{mol} / \mathrm{l})$. It should be mentioned at the node connection that temperature difference at each node causes density change, therefore concentration is compensated based on the temperature at node as follows;

$$
C_{i}^{j, i n}=\frac{\rho_{j}}{\rho_{j-1}} C_{i}^{j-1, \text { out }}
$$

where $\rho_{j}$ : density of water at node $j\left(\mathrm{~kg} / \mathrm{m}^{3}\right), \rho_{j-1}$ : density of water at node $j-1\left(\mathrm{~kg} / \mathrm{m}^{3}\right)$. 


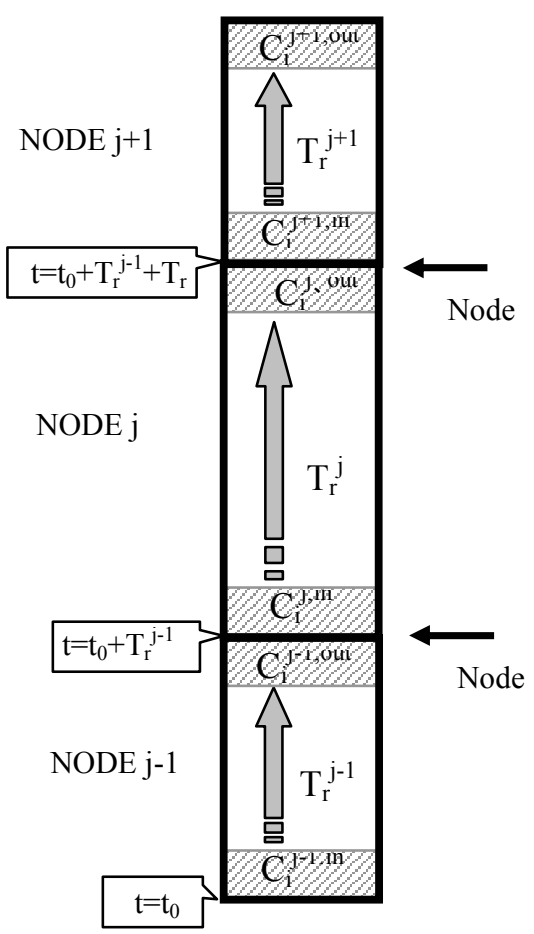

Fig. 3 Node connection with adjacent nodes.

Table 2 High temperature G-values ${ }^{(4)}$.

\begin{tabular}{|c|c|c|}
\hline Species & Gamma rays & Neutrons \\
\hline $\mathrm{e}^{-}$ & 3.50 & 0.60 \\
$\mathrm{H}$ & 0.90 & 0.50 \\
$\mathrm{H}^{+}$ & 3.50 & 0.60 \\
$\mathrm{H}_{2}$ & 0.60 & 1.50 \\
$\mathrm{H}_{2} \mathrm{O}_{2}$ & 0.55 & 1.14 \\
$\mathrm{HO}_{2}$ & 0.00 & 0.04 \\
$\mathrm{OH}^{-}$ & 4.50 & 1.70 \\
$\mathrm{OH}^{-}$ & 0.00 & 0.00 \\
\hline
\end{tabular}

One of the typicality on calculation of the irradiation loop system is wide range temperature distribution from R.T. to about $573 \mathrm{~K}$. To treat such a wide range temperature distribution, reaction rate constants were given by extrapolation from the $561 \mathrm{~K}$ values assuming Arrhenius equation and activation energy as follows;

$$
k(T)=k\left(T_{0}\right) \exp \left\{\left(\frac{1}{T_{0}}-\frac{1}{T_{i}}\right) \frac{Q}{R}\right\}
$$

where $T_{0}$ :standard temperature $(\mathrm{K}), T_{i}$ : temperature at a node $(\mathrm{K}), Q$ : activation energy $(\mathrm{J} / \mathrm{mol}), k$ : reaction rate constant $(1 / \mathrm{mol} / \mathrm{s}), R$ : gas constant $(8.31 \mathrm{~J} / \mathrm{mol} / \mathrm{K})$. Reaction rate constants and activation energy ${ }^{(4) \sim(6)}$ employed in this study is shown in Table 3.

Main components in the irradiation loop system were modeled into several regions. Fig. 4 shows the calculation model for the irradiation loop system. Normally main components 
Table 3 Rate constants and activation energies ${ }^{(4) \sim(6)}$.

\begin{tabular}{|c|c|c|c|c|}
\hline \multirow[t]{2}{*}{ Reaction } & \multicolumn{2}{|c|}{$\begin{array}{l}\text { Rate constant at } 558 \mathrm{~K} \\
\qquad\left(\mathrm{dm}^{3} / \mathrm{mol} / \mathrm{s}\right)\end{array}$} & Activation & \multirow{2}{*}{$\begin{array}{l}\text { Energy } \\
\qquad(\mathrm{J} / \mathrm{mol}) \\
\text { REVERSE }\end{array}$} \\
\hline & FORWARD & REVERSE & FORWARD & \\
\hline $\mathrm{H}^{+}+\mathrm{OH}^{-} \rightarrow \mathrm{H}_{2} \mathrm{O}$ & $1.90 \times 10^{12}$ & & $1.26 \times 10^{4}$ & \\
\hline $\mathrm{H}_{2} \mathrm{O}_{2} \rightarrow 1 / 2 \mathrm{O}_{2}+\mathrm{H}_{2} \mathrm{O}$ & $1.40 \times 10^{-2} *$ & & $6.00 \times 10^{4}$ & \\
\hline $\mathrm{e}^{-}+\mathrm{H}_{2} \mathrm{O} \rightarrow \mathrm{H}+\mathrm{OH}^{-}$ & $2.90 \times 10^{2}$ & & $1.26 \times 10^{4}$ & \\
\hline $\mathrm{e}^{-}+\mathrm{H}+\rightarrow \mathrm{H}$ & $2.60 \times 10^{11}$ & & $1.26 \times 10^{4}$ & \\
\hline $\mathrm{e}^{-}+\mathrm{OH} \rightarrow \mathrm{OH}^{-}$ & $2.90 \times 10^{11}$ & & $1.26 \times 10^{4}$ & \\
\hline $\mathrm{e}^{-}+\mathrm{H}_{2} \mathrm{O}_{2} \rightarrow \mathrm{OH}+\mathrm{OH}^{-}$ & $2.40 \times 10^{11}$ & & $1.26 \times 10^{4}$ & \\
\hline $\mathrm{H}+\mathrm{H} \rightarrow \mathrm{H}_{2}$ & $9.00 \times 10^{10}$ & & $1.26 \times 10^{4}$ & \\
\hline $\mathrm{e}^{-}+\mathrm{HO}_{2} \rightarrow \mathrm{HO}_{2}^{-}$ & $3.00 \times 10^{11}$ & & $1.26 \times 10^{4}$ & \\
\hline $\mathrm{e}^{-}+\mathrm{O}_{2} \rightarrow \mathrm{O}_{2}^{-}$ & $2.60 \times 10^{11}$ & & $1.26 \times 10^{4}$ & \\
\hline $2 \mathrm{e}^{-}+2 \mathrm{H}_{2} \mathrm{O} \rightarrow \mathrm{H}_{2}+2 \mathrm{OH}^{-}$ & $1.75 \times 10^{6}$ & & $1.26 \times 10^{4}$ & \\
\hline $2 \mathrm{OH} \rightarrow \mathrm{H}_{2} \mathrm{O}_{2}$ & $2.50 \times 10^{10}$ & & $8.40 \times 10^{3}$ & \\
\hline $\mathrm{OH}^{-}+\mathrm{H} \rightarrow \mathrm{e}^{-}+\mathrm{H}_{2} \mathrm{O}$ & $7.00 \times 10^{8}$ & & $1.26 \times 10^{4}$ & \\
\hline $\mathrm{e}^{-}+\mathrm{H}+\mathrm{H}_{2} \mathrm{O} \rightarrow \mathrm{OH}-+\mathrm{H}_{2}$ & $4.82 \times 10^{9}$ & & $1.26 \times 10^{4}$ & \\
\hline $\mathrm{e}^{-}+\mathrm{HO}_{2}^{-}+\mathrm{H}_{2} \mathrm{O} \rightarrow \mathrm{OH}+2 \mathrm{OH}^{-}$ & $5.35 \times 10^{8}$ & & $1.26 \times 10^{4}$ & \\
\hline $\mathrm{H}+\mathrm{OH} \rightarrow \mathrm{H}_{2} \mathrm{O}$ & $2.30 \times 10^{11}$ & & $1.26 \times 10^{4}$ & \\
\hline $\mathrm{OH}+\mathrm{H}_{2} \rightarrow \mathrm{H}+\mathrm{H}_{2} \mathrm{O}$ & $1.40 \times 10^{9}$ & & $1.93 \times 10^{4}$ & \\
\hline $\mathrm{H}+\mathrm{O}_{2} \rightarrow \mathrm{HO}_{2}$ & $1.50 \times 10^{11}$ & & $1.26 \times 10^{4}$ & \\
\hline $\mathrm{H}+\mathrm{HO}_{2} \rightarrow \mathrm{H}_{2} \mathrm{O}_{2}$ & $3.00 \times 10^{11}$ & & $1.26 \times 10^{4}$ & \\
\hline $\mathrm{H}+\mathrm{O}_{2}^{-} \rightarrow \mathrm{HO}_{2}^{-}$ & $3.00 \times 10^{11}$ & & $1.26 \times 10^{4}$ & \\
\hline $\mathrm{e}^{-}+\mathrm{O}_{2}^{-}+\mathrm{H}_{2} \mathrm{O} \rightarrow \mathrm{HO}_{2}^{-}+\mathrm{OH}^{-}$ & $3.57 \times 10^{9}$ & & $1.26 \times 10^{4}$ & \\
\hline $\mathrm{H}+\mathrm{H}_{2} \mathrm{O}_{2} \rightarrow \mathrm{OH}+\mathrm{H}_{2} \mathrm{O}$ & $2.00 \times 10^{9}$ & & $1.89 \times 10^{4}$ & \\
\hline $\mathrm{OH}+\mathrm{H}_{2} \mathrm{O}_{2} \rightarrow \mathrm{H}_{2} \mathrm{O}+\mathrm{HO}_{2}$ & $4.20 \times 10^{8}$ & & $1.43 \times 10^{4}$ & \\
\hline $\mathrm{OH}+\mathrm{HO}_{2} \rightarrow \mathrm{H}_{2} \mathrm{O}+\mathrm{O}_{2}$ & $1.00 \times 10^{11}$ & & $1.26 \times 10^{4}$ & \\
\hline $2 \mathrm{HO}_{2} \rightarrow \mathrm{H}_{2} \mathrm{O}_{2}+\mathrm{O}_{2}$ & $5.00 \times 10^{7}$ & & $1.89 \times 10^{4}$ & \\
\hline $\mathrm{HO}_{2} \rightarrow \mathrm{O}_{2}^{-}+\mathrm{H}^{+}$ & $3.90 \times 10^{5} *$ & $7.70 \times 10^{11}$ & $1.26 \times 10^{4}$ & $1.26 \times 10^{4}$ \\
\hline $\mathrm{HO}_{2}+\mathrm{O}_{2}^{-} \rightarrow \mathrm{O}_{2}+\mathrm{HO}_{2}^{-}$ & $5.00 \times 10^{8}$ & & $1.89 \times 10^{4}$ & \\
\hline $\mathrm{O}_{2}^{-}+\mathrm{OH} \rightarrow \mathrm{OH}^{-}+\mathrm{O}_{2}$ & $2.90 \times 10^{11}$ & & $1.26 \times 10^{4}$ & \\
\hline $2 \mathrm{O}_{2}^{-}+2 \mathrm{H}_{2} \mathrm{O} \rightarrow \mathrm{O}_{2}+\mathrm{H}_{2} \mathrm{O}_{2}+2 \mathrm{OH}^{-}$ & $1.27 \times 10^{5}$ & & $1.89 \times 10^{4}$ & \\
\hline $\mathrm{H}_{2} \mathrm{O}_{2}+\mathrm{OH}^{-} \rightarrow \mathrm{HO}_{2}^{-}+\mathrm{H}_{2} \mathrm{O}$ & $1.00 \times 10^{10}$ & $2.14 \times 10^{5}$ & $1.26 \times 10^{4}$ & $1.26 \times 10^{4}$ \\
\hline${ }^{+} \mathrm{H}_{2} \mathrm{O}_{2} \rightarrow 2 \mathrm{OH}$ & $2.3 \times 10^{-4} * *$ & & $6.00 \times 10^{4}$ & \\
\hline
\end{tabular}

such as heat exchangers and pipes have temperature distribution. Therefore, such main components were divided to several nodes to introduce the temperature effect. The capsule was also modeled into several nodes in connection with the structure and fluence distribution. Modeling of the in-pile region is shown in Fig.5. In the capsule, large amount of test specimens are installed, then input information such as surface area, volume were evaluated precisely.

One through type calculation is performed for the irradiation loop system. According to the calculation model shown in Fig.4, contents of $\mathrm{O}_{2}, \mathrm{H}_{2}, \mathrm{H}_{2} \mathrm{O}_{2}$ and other radicals is calculated along with the water flow. In the calculation, consumption of oxidizing species due to oxidation of metallic surface is not considered because enough prefilming treatment by high temperature as well as highly oxygen concentrated water had been performed before the loop operation. 


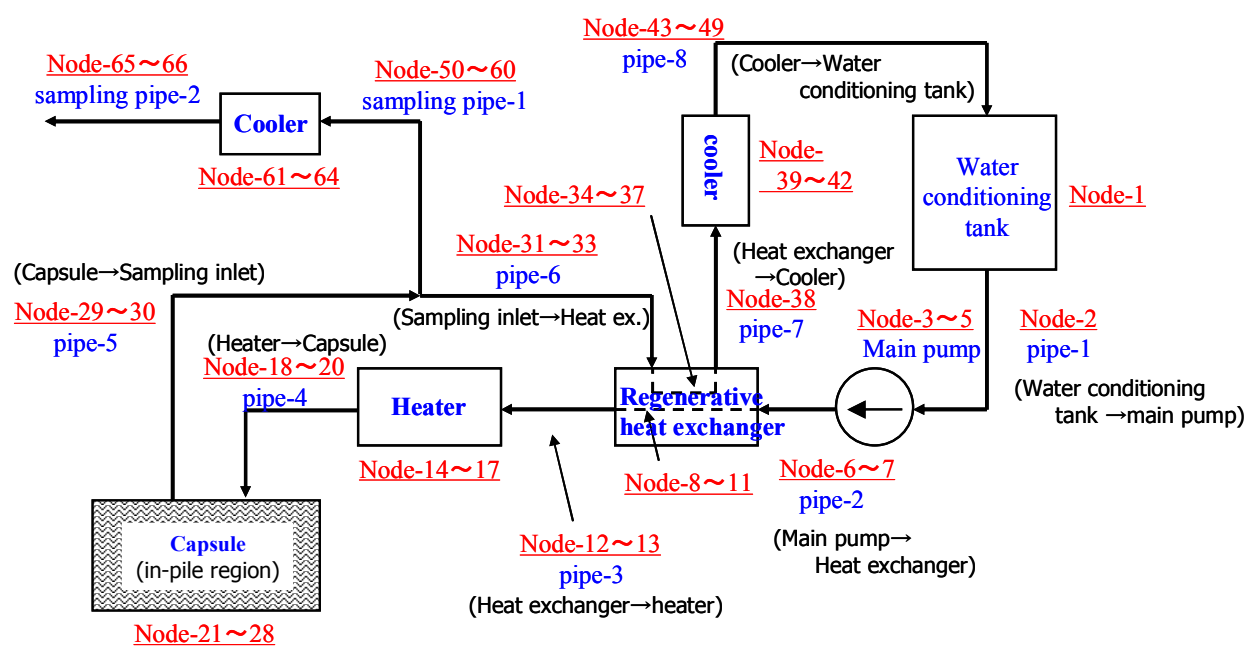

Fig. 4 Calculation model for the irradiation loop system.

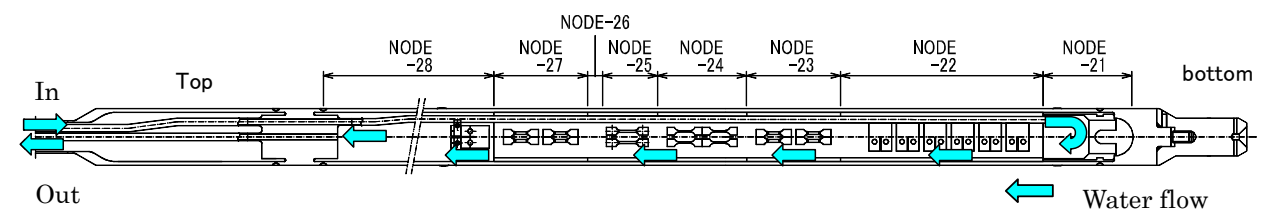

Fig. 5 Calculation model for the in-pile region.

\section{Discussions}

\subsection{Water chemistry measurement}

In order to evaluate water chemistry variables in the irradiation loop system, $\mathrm{O}_{2}$ concentration, $\mathrm{H}_{2}$ concentration and $\mathrm{H}_{2} \mathrm{O}_{2}$ concentration are measured by online monitoring or batch sampling. In viewpoint of corrosion phenomenon, it is well known that $\mathrm{O}_{2}$ and $\mathrm{H}_{2} \mathrm{O}_{2}$ are important parameters because they increase the electrochemical corrosion potential (ECP) of stainless steel, whereas hydrogen decrease the ECP. At the outlet of the water conditioning tank, the water chemistry is monitored not only for evaluation but also to control $\mathrm{O}_{2}$ concentration, $\mathrm{H}_{2}$ concentration in supply water. In addition, outlet water as well as inlet water of the in-pile region is measured by selecting sampling selection valves as shown in Fig.1. In the irradiation loop system, $\mathrm{O}_{2}$ concentration and $\mathrm{H}_{2}$ concentration are

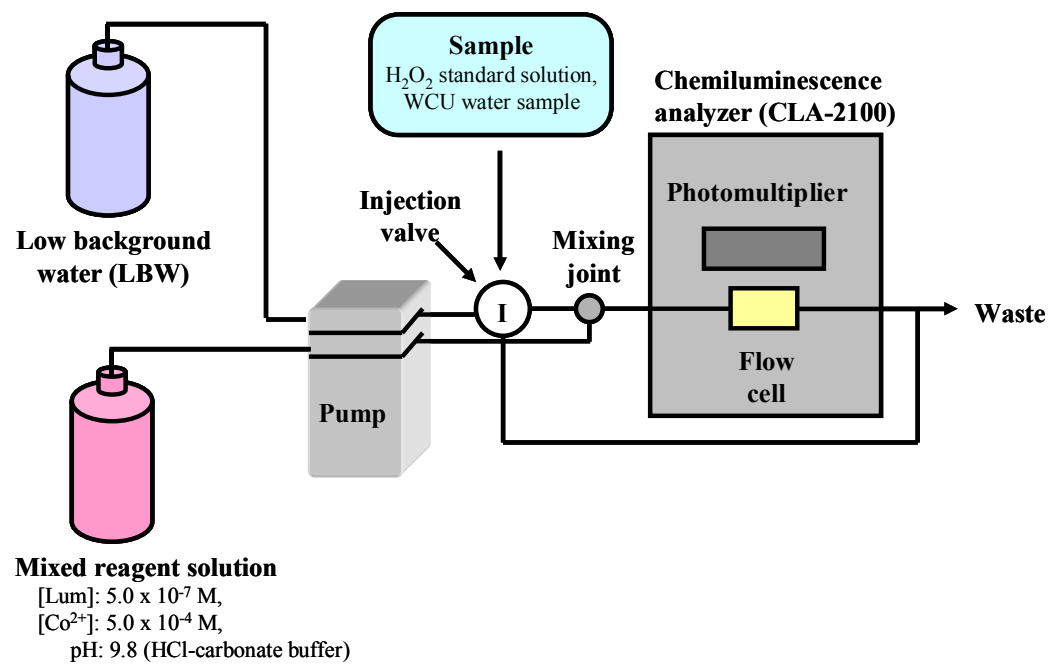

Fig. 6 Apparatus for determination of $\mathrm{H}_{2} \mathrm{O}_{2}$. 
measured by polarographic type sensors (DKK-TOA Co.Ltd.), and these are installed in the WCU for online monitoring. On the other hand, measurement method for $\mathrm{H}_{2} \mathrm{O}_{2}$ concentration is quite different from others. For understanding the concentration of $\mathrm{H}_{2} \mathrm{O}_{2}$ in the irradiation loop, high detection level of sub-ppb is required. One of the most promising methods for $\mathrm{H}_{2} \mathrm{O}_{2}$ detection is the chemical photoluminescence, using luminol as a chemical phosphor. In order to detect $\mathrm{H}_{2} \mathrm{O}_{2}$ by the chemical photoluminescence method, the flow injection type $\mathrm{H}_{2} \mathrm{O}_{2}$ detection method ${ }^{(7)}$ was employed in the irradiation loop system. A schematic diagram of this method is shown in Fig.6. The carrier water is supplied continuously into a mixing joint. The mixed reagent which is consisted of luminol, $\mathrm{Co}^{2+}$, and buffer solution and carrier water are fed into the mixing joint with the same flow rate. $20 \mu \mathrm{l}$ of sample water are fed into the mixing joint by rotating the injection valve. $\mathrm{H}_{2} \mathrm{O}_{2}$ in the sample water reacts with the luminol on passing into the flow cell. Then the luminous intensity is measured by the chemiluminescence analyzer CLA-2100 (Tohoku Electronic Industrial Co.,Ltd.).

\subsection{Evaluation}

In this study, distributions of $\mathrm{O}_{2}, \mathrm{H}_{2}$ and $\mathrm{H}_{2} \mathrm{O}_{2}$ in the capsule as well as in the WCU were calculated using the WRAC-JM code. The absorption dose rate distribution of neutron as well as $\gamma$-ray for in-pile region is shown in Fig.7. Values of the absorption dose rate are described in Table 4. Major input parameters such as temperature, surface area/volume $(\mathrm{S} / \mathrm{V})$ ratio and residence time for each node in WCU and in-pile region are described in Table 5. In this table, parameters are indicated as range (min-max) for each component. It is clear from this table that $\mathrm{S} / \mathrm{V}$ ratio at the capsule is quite large compared to that of other components. In order to confirm the applicability of water radiolysis code, several cases were calculated. Calculation cases are shown in Table 6. In this table, values mean the initial condition at the water conditioning tank and three of four cases simulate NWC condition, the rest simulates HWC conditions.

Fig. 8 shows comparison between measured and calculated result at the sampling point of the irradiation loop system. In this figure, horizontal-axis shows the measured values and vertical-axis shows the calculated values, (a), (b), (c) and (d) show concentration of $\mathrm{H}_{2} \mathrm{O}_{2}$, $\mathrm{H}_{2}, \mathrm{O}_{2}$ and effective oxygen concentration ( $\left[\mathrm{O}_{2}\right]_{\mathrm{eff}}$ ), respectively. $\left(\left[\mathrm{O}_{2}\right]_{\mathrm{eff}}\right.$ is defined as $\left[\mathrm{O}_{2}\right]_{\mathrm{eff}}$ $=\left[\mathrm{O}_{2}\right]+1 / 2\left[\mathrm{H}_{2} \mathrm{O}_{2}{ }^{\left({ }^{(8)}\right.}\right.$ ) From this figure, it can be said that $\mathrm{O}_{2}, \mathrm{H}_{2}$ concentration and $\left[\mathrm{O}_{2}\right]_{\text {eff }}$ relatively agree well with measured data. On the other hand, measured $\mathrm{H}_{2} \mathrm{O}_{2}$ concentration was quite small since $\mathrm{H}_{2} \mathrm{O}_{2}$ decomposes by heat during passing through the high temperature area at the sampling line. From the comparison between measured and calculated result on $\mathrm{H}_{2} \mathrm{O}_{2}$ concentration, good enough coincidence cannot be observed. One of the reasons for this is considered that temperature measurement point around the

Table 4 Absorption dose rate at in-pile region.

\begin{tabular}{|c|c|c|}
\hline \multirow{2}{*}{ Position } & \multicolumn{2}{|c|}{ Absorption dose rate (Gy/s) } \\
\cline { 2 - 3 } & Neutron & $\gamma$-ray \\
\hline \hline node 28 & 142 & 307 \\
\hline node 27 & 372 & 603 \\
\hline node 26 & 487 & 823 \\
\hline node 25 & 574 & 988 \\
\hline node 24 & 818 & 1040 \\
\hline node 23 & 926 & 1020 \\
\hline node 22 & 766 & 962 \\
\hline node 21 & 613 & 952 \\
\hline
\end{tabular}


Table 5 Major input parameters.

\begin{tabular}{|c|c|c|c|c|c|}
\hline Components & Node & $\begin{array}{c}\text { Temperature } \\
(\mathrm{K})\end{array}$ & $\begin{array}{l}\text { S/V ratio } \\
(1 / \mathrm{m})\end{array}$ & $\begin{array}{c}\text { Residence Time } \\
\text { (sec) }\end{array}$ & $\begin{array}{l}\text { Flow velocity } \\
\qquad(\mathrm{m} / \mathrm{sec})\end{array}$ \\
\hline Water conditioning tank & 1 & 310 & - & - & - \\
\hline Pipe-1 & 2 & 310 & 142 & 4.6 & 0.48 \\
\hline Main pump & $3-5$ & 310 & $94-160$ & $17.3-26.4$ & $0.21-0.60$ \\
\hline Pipe-2 & $6-7$ & 310 & 206 & 6.0 & $0.84-1.00$ \\
\hline Heat exchanger & $8-11$ & $346-452$ & $104-308$ & $26.4-32.8$ & $0.22-0.43$ \\
\hline Pipe-3 & $12-13$ & 452 & 206 & $4.4-9.2$ & $0.26-0.94$ \\
\hline Heater & $14-17$ & $469-521$ & 46 & $105.0-113.8$ & $\begin{array}{c}0.0035- \\
0.0038\end{array}$ \\
\hline Pipe-4 & $18-20$ & $521-523$ & $160-666$ & $1.9-13.4$ & $0.18-3.06$ \\
\hline Capsule & $21-28$ & $524-556$ & $\begin{array}{l}105- \\
1891 \\
\end{array}$ & $0.3-8.3$ & $\begin{array}{c}0.056- \\
0.213\end{array}$ \\
\hline Pipe-5 & $29-30$ & 541 & $280-667$ & $5.8-13.2$ & $0.56-3.18$ \\
\hline Pipe-6 & $31-33$ & 522 & $104-280$ & $2.0-5.4$ & $0.075-1.04$ \\
\hline Heat exchanger & $34-37$ & $419-488$ & $104-217$ & $2.8-19.3$ & $0.25-1.05$ \\
\hline Pipe-7 & 38 & 385 & 206 & 4.3 & 0.88 \\
\hline Cooler & $39-42$ & $327-366$ & $104-217$ & $3.1-25.8$ & $0.22-0.95$ \\
\hline Pipe-8 & $43-49$ & 308 & $13-206$ & $1.9-317.4$ & $0.006-1.0$ \\
\hline Sampling pipe-1 & $50-60$ & $541-476$ & $114-920$ & $0.2-51.8$ & $0.008-0.56$ \\
\hline Cooler & $61-64$ & $472-306$ & 261 & $40.0-46.0$ & $\begin{array}{c}0.041- \\
0.036\end{array}$ \\
\hline Sampling pipe-2 & $65-66$ & 306 & $273-513$ & $24.5-100.6$ & $0.14-0.28$ \\
\hline
\end{tabular}

Table 6 Calculation cases.

\begin{tabular}{|c|c|c|c|c|}
\hline Condition & & {$\left[\mathrm{O}_{2}\right](\mathrm{ppb})$} & {$\left[\mathrm{H}_{2}\right](\mathrm{ppb})$} & {$\left[\mathrm{H}_{2} \mathrm{O}_{2}\right](\mathrm{ppb})$} \\
\hline \multirow{3}{*}{ NWC } & Case-1 & 170 & 2 & 9 \\
\cline { 2 - 5 } & Case-2 & 50 & 3 & 16 \\
\cline { 2 - 5 } & Case-3 & 10 & 4 & 10 \\
\hline \multirow{2}{*}{ HWC } & Case-4 & 0 & 60 & 14 \\
\hline
\end{tabular}

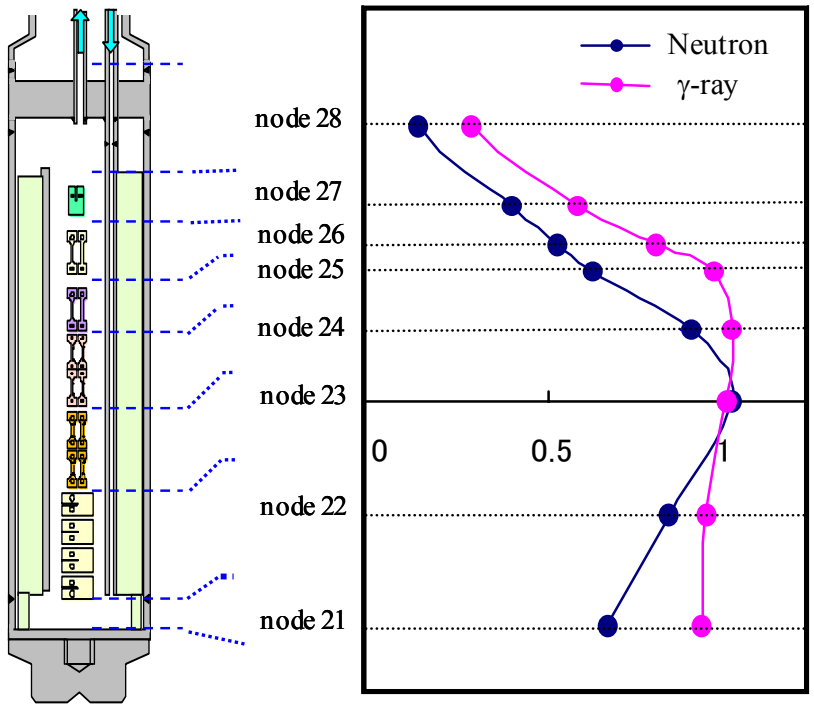

Fig. 7 Absorption dose rate distribution at in-pile region. 
sampling line in the irradiation loop system is not enough to evaluate the decomposition behavior of $\mathrm{H}_{2} \mathrm{O}_{2}$. Therefore precise temperature evaluation of sampling line is required for more precise $\mathrm{H}_{2} \mathrm{O}_{2}$ evaluation.

Fig.9 shows the water chemistry distributions obtained by the WRAC-JM. In Fig.9, (a), (b), (c) and (d) show concentration of $\mathrm{H}_{2} \mathrm{O}_{2}, \mathrm{H}_{2}, \mathrm{O}_{2}$ and $\left[\mathrm{O}_{2}\right]_{\text {eff }}$, respectively. Each concentration depends on location in the irradiation loop system. Typically, the extreme change in concentration is observed at the irradiation field due to water radiolysis by neutron or gamma-ray. In view point of IASCC irradiation research, the water chemistry at the irradiation field is of much interest. In case of $\mathrm{NWC}, \mathrm{H}_{2} \mathrm{O}_{2}$ concentration increased up to 250ppb in case- $1, \mathrm{O}_{2}$ as well as $\mathrm{H}_{2} \mathrm{O}_{2}$ decreases by decreasing $\mathrm{O}_{2}$ injection. In case of $\mathrm{HWC}$, increase of $\left[\mathrm{O}_{2}\right]$ eff was governed by $\mathrm{H}_{2} \mathrm{O}_{2}$ but it suppressed at quite low level lower than $15 \mathrm{ppb}$.

Employing the water radiolysis code, precise water chemistry at the in-pile region as well as out-pile region, relation of the initial condition of supply water and water chemistry in the in-pile region can be evaluated. In other words, important information for IASCC irradiation tests can be obtained by this water radiolysis code. However, it should be mentioned that calculated results at the irradiation field is not confirmed by the direct measurement. Hence, based on the corrosive environmental standpoint, validation by ECP measurement is expected.



(a) Hydrogen peroxide concentration

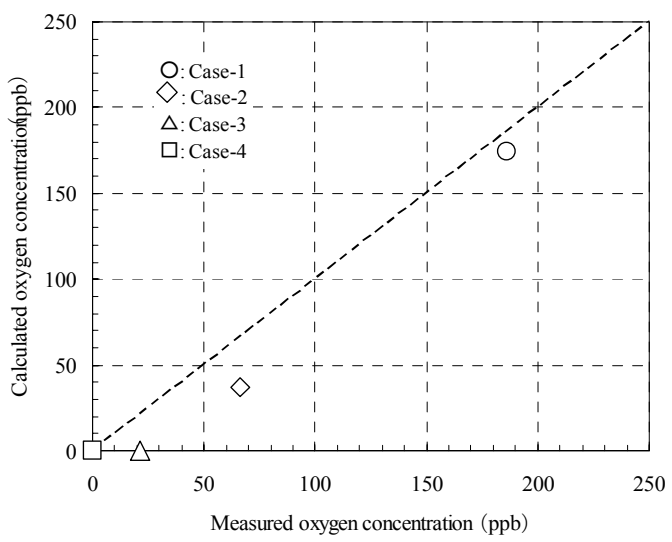

(c) Oxygen concentration

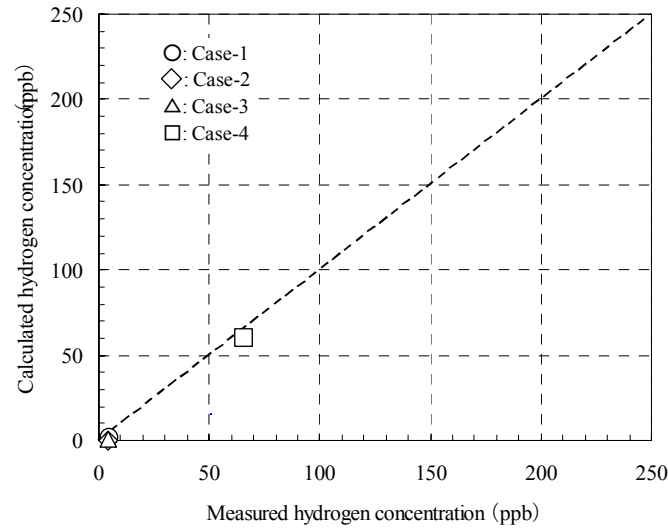

(b) Hydrogen concentration

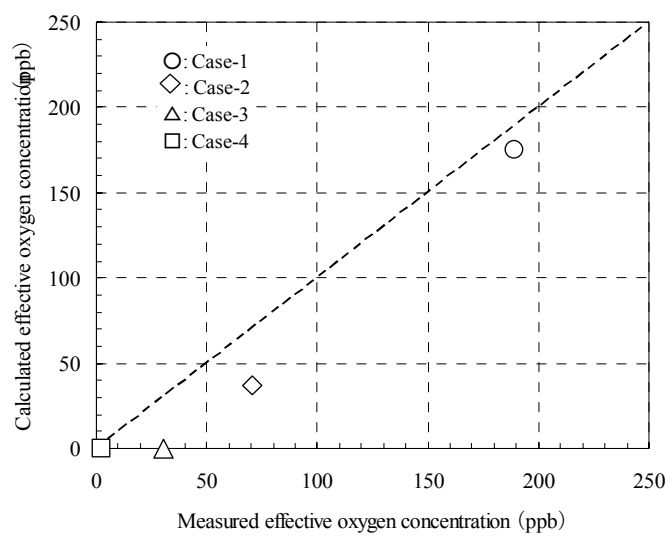

(d) Effective oxygen concentration

Fig. 8 Comparison between measured and calculated results. 


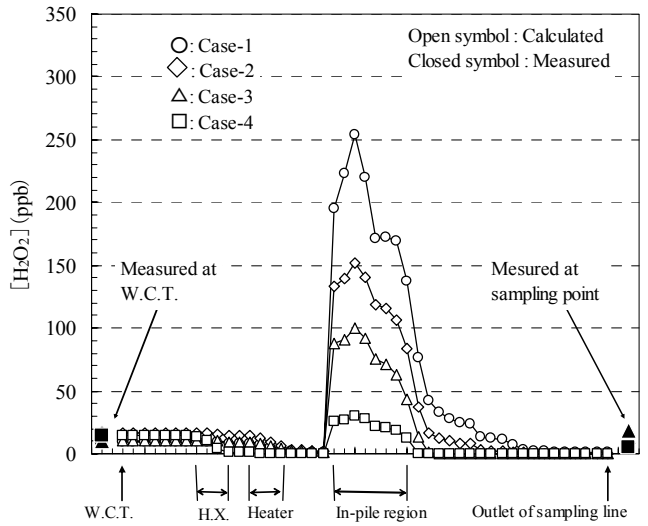

(a) Hydrogen peroxide concentration

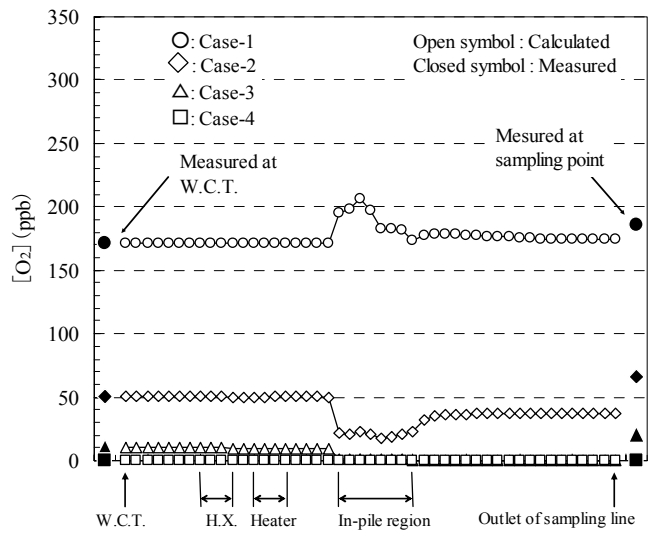

(c) Oxygen concentration

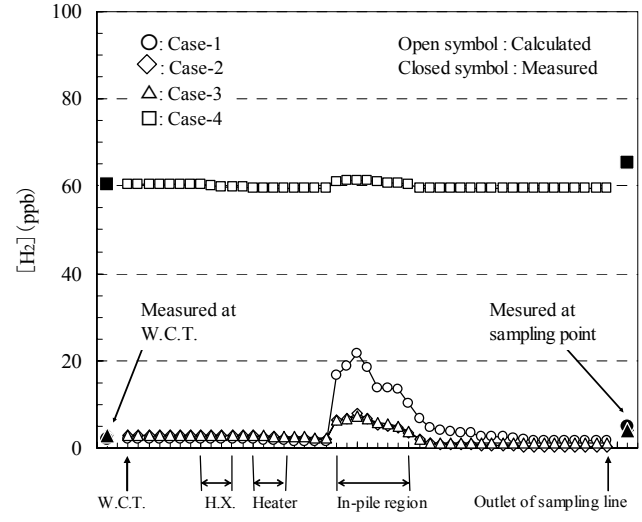

(b) Hydrogen concentration

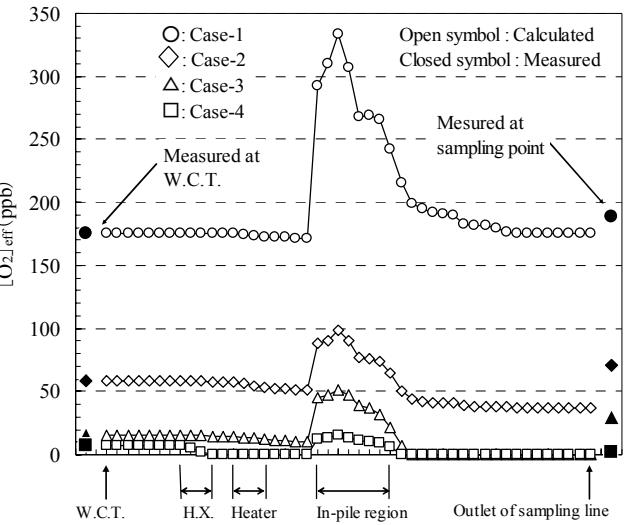

(d) Effective oxygen concentration

Fig. 9 Water chemistry distribution obtained by the WRAC-JM.

\section{Conclusions}

In this study, the water radiolysis code for irradiation loop system was developed. Calculation results obtained by the developed water radiolysis code were compared with experimental data. The comparison results on $\mathrm{O}_{2}, \mathrm{H}_{2}$ concentration and $\left[\mathrm{O}_{2}\right]_{\text {eff }}$ showed relatively good agreement between calculation results and experimental data. Further, water chemistry at the irradiation field which gives important information for IASCC irradiation research can be obtained from the water radiolysis code.

\section{References}

(1) Satoh, T. et al.,Water Chemistry in a Crack Tip under Irradiation, Journal of Nuclear Science and Technology, Vol.40, No.5 (2003), pp.334-342.

(2) Matsui, Y. et al., Irradiation techniques under high pressurized water using hybrid type saturated temperature capsule in the JMTR, Journal of Nuclear Materials, Vol.258-263 (1998), pp.378-382.

(3) Ide, H. et al., Thermohydraulic Design of Saturated Temperature Capsule for IASCC Irradiation Test, JAERI-Tech 2002-079 (2002).

(4) Uchida, S. et al, Crevice Chemistry under Gamma Ray Irradiation, Proceedings of 10th International Symposium on Environmental Degradation of Materials in Nuclear Power Systems - Water Radiolysis, Lake Tahoe, Nevada, August 5-9, 2001, (2001).

(5) Ibe, E. and Uchida, S., Analytical Evaluation of Water Radiolysis in BWRs, Proceedings of International Conference on Water Chemistry of Nuclear Reactor System, Water chemistry 3. BNES, London, (1983), pp.17-27.

(6) Uchida, S. et al., Effects of Hydrogen Peroxide on Intergranular Stress Corrosion Cracking 
of Stainless Steel in High Temperature Water, Journal of Nuclear Science and Technology, Vol.35, No.4 (1998), 301-308.

(7) Yamashiro, N. et al., Determination of Hydrogen Peroxide in Water by Chemiluminescence Detection, Journal of Nuclear Science and Technology, Vol.41, No.9 (2004) pp.890-897.

(8) Nakata, K. et al., Effects of Gamma-ray Irradiation on Crack Growth of Sensitized Type 304 Stainless Steel in $288^{\circ} \mathrm{C}$ Water, Corrosion, Vol.49, No.11 (1993) pp.903-909. 